\title{
Krokot Extract (Portulaca Oleracea. L) As Natural Light-harvesting pigments for Dye-Sensitized Solar Cells (DSSCs): Influence of Dye Acidity
}

\author{
Cici Nurfaizah, Didik Krisdiyanto*, Khamidinal and Sudarlin \\ Department of Chemistry, Faculty of Science and Technology, UIN Sunan Kalijaga \\ Jl. Marsda Adisucipto No 1 Yogyakarta 55281, Indonesia. Tel. +62-274-540971, Fax. +62-274-519739 \\ Author correspondency*: \\ didik_kris@yahoo.com
}

\begin{abstract}
Dye-sensitized solar cells (DSSCs) was fabricated using natural dyes extracted from krokot (Portulaca Oleracea. L). The effect of dye acidity was investigated on natural $\mathrm{pH}$ extract, $5.00,4.00$ and $3.00 \mathrm{of} \mathrm{pH}$. The efficiency and stability DSSCs as a function of the dye acidity was studied. The result of the UV-Vis shows that the absorption of wave-length from dye extract of krokot is located in the visible region with the absorbance peak in $410.5 \mathrm{~nm}$ and $664.5 \mathrm{~nm}$ which are the peak of chlorophyll. The efficiency of extract krokot dye sensitized solar cells was decreasing $6.88 \times 10-3 \%$ to $0.42 \times 10-3 \%$ when $\mathrm{pH}$ of the dye was adjusted from 6.27 to 3.00 . DSSCs stability was also decreased look for efficiency loss from $5.27 \%$ to $97.49 \%$ in the same conditions.
\end{abstract}

Keywords: Dye Sensitized Solar Cell (DSSCs), chlorophyll, efficiency

\section{Introduction}

Portulaca oleracea L. is a warm-climate, herbaceous succulent annual plant with a cosmopolitan distribution belonging to the Portulacaceae family (Xi Zhou et al., 2015). Many constituents of Portulaca oleracea have been isolated, including alkaloids, beta-carotene, betasitosterol, caffeic acid, catechol, chlorophyll, coumarins, DHA, EPA, ferulic acid, flavanoids, saponins and tannin (Esiyok et al., 2004), (Palaniswamy et al., 2001), (Mohamed and Hussein, 1994).

The green pigmented chlorophyll has the desirable photovoltaic properties that are utilized in today's organic photosynthetic solar cells.

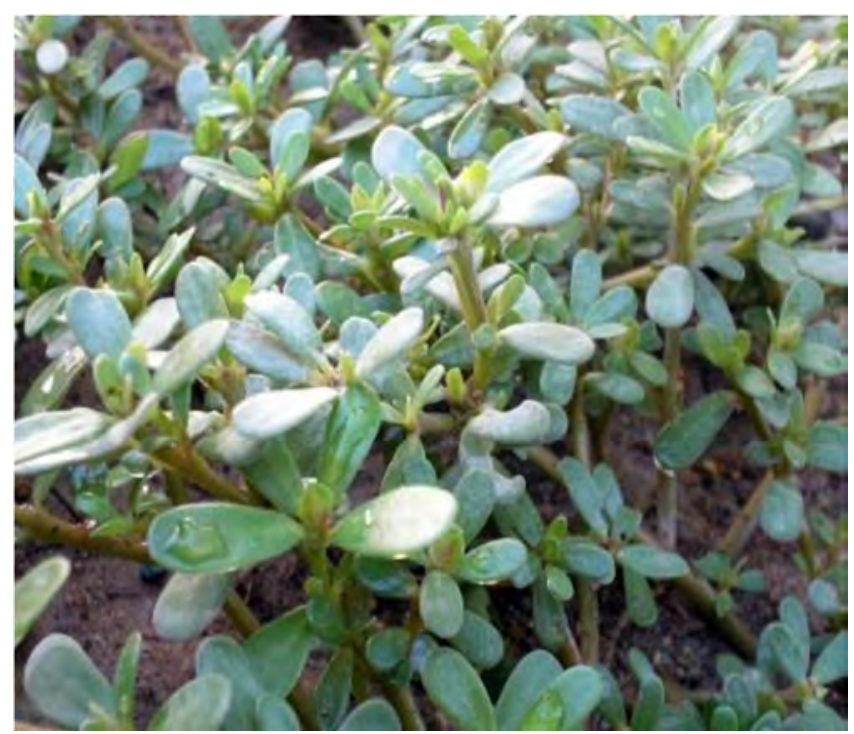

Figure 1. The Portulaca oleracea L plants.
Chlorophyll is a light harvesting pigment that absorbs light in the visible spectrum of solar radiation which promotes electron transfer. Carotenoids are also an important part of the photosynthetic process. They aid in energy transfer to the chlorophyll molecule, and serve to supplement the light gathering properties of chlorophyll (Diarra et al., 1986). Appropriate plant species for use in photosynthetic solar cell applications are those with high concentrations of chlorophyll alpha and chlorophyll beta. Krokot or Purslane (Portulaca oleracea) have been found to contain high concentrations of chlorophyll alpha and beta (Griffin et al., 2004).

The idea of using the reactions of photosynthesis to convert light into electrical power appeared already Melvin Calvin before 1974 (Hug et al., 2013). Sun light excited the electrons of pigment into higher energy level then transfered to the conduction band of the wide band gap semiconductor. The model based on a synthetic membrane where carotenoids were used as a wire inside the membrane. After absorption of a light by a sensitizer molecule at one side of the membrane, the electron is transfered to a carotenoid and then diffuse through the membrane the the other side where it is captured by ellectron acceptor. Dye-sensitized solar cells (DSSCs) are belonging to the third generation photovoltaics concept where used natural dyes as light harvesting pigment (Kalyanasundaram and Graetzel, 2010; Hagfeldt et al., 2010). They are also called Graetzel cells (O'regan and Graetzel, 1991)

The advantages of natural dyes as photosensitizer are large adsorption coefficients, high light-harvesting efficiency, no resource limitations, low cost, easy prepared and no harm to the environment (Luo et al., 2009). Chlorophyll is the principal pigments in natural photosynthetic system. It is a green pigment found in the 
leaves of most green plant, algae and cyanobacteria. Six different types of chlorophyll pigment exist and the most occuring types is chlorophyll $\alpha$. The molecular structure include a chlorine ring with $\mathrm{Mg}$ center, along with different side chains and a hydrocarbon trail depending on the chlorophyll type (Ludin et al., 2014). Their function include harvesting sunlight, converting solar energy to chemical enery and tranferring electrons. Chlorohyll and their derivatives are inserted into DSSCs as dye sensitizer because of their beneficial light absorption tendency modes. Chlorophyll has an absorption maximum at $670 \mathrm{~nm}$ because of an attractive compound that acts as an photosensitizer the visible light range (Wang et al. 2010)

A DSSC consists of a pair of coated glass TCO substrate (Transparent Conducting Oxide) as the electrode and the counter electrode, the redox electrolyte that contains iodide and triiodide ion $\left(\mathrm{I}-/ \mathrm{I}_{3}{ }^{-}\right)$carbon layer as the catalyst, porous $\mathrm{TiO} 2$ nanocrystal as fotoanoda, and a dye photosensitizer. All components are arranged in front of the sandwich structure where the top layer is the working electrode as the initial layer in receiving photons and the lower layer is the counter electrode and the middle is electrolyte to regenerate electron. Dye criteria that can be used as a dye sensitizer is adsorption intensity at visible wavelengths, strong adsorption on the surface of the semiconductor, has the ability to inject electrons to the band conduction of the semiconductor, and has a group $=\mathrm{O}$ or $-\mathrm{H}$ to bind to the surface of $\mathrm{TiO} 2$ which can increase the reaction rate of the electron transfer.

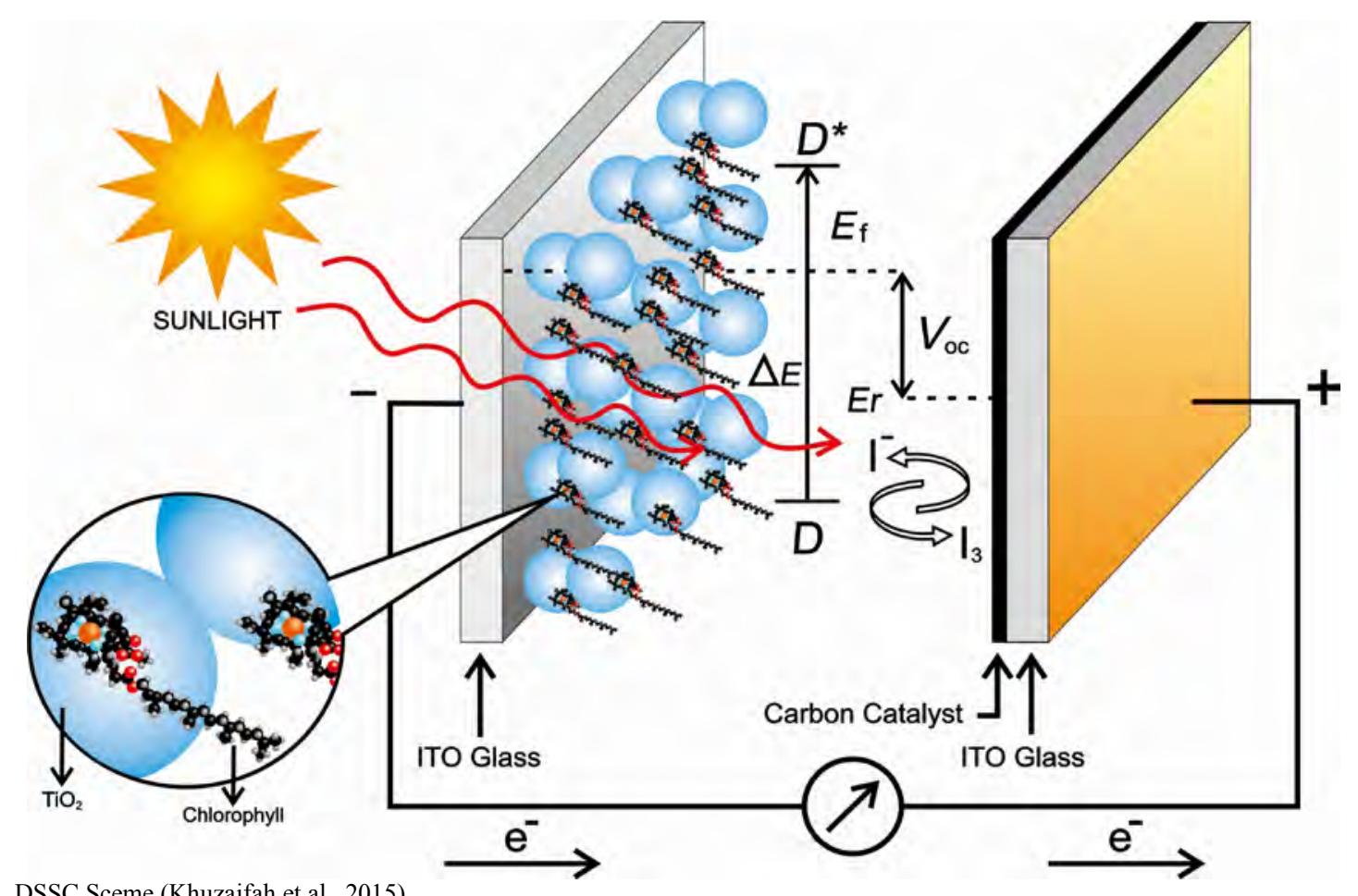

Figure 2. DSSC Sceme (Khuzaifah et al., 2015).

Therefore, this study will utilize the potential of the natural dye that derived from extracts of krokot which are expected to fulfill the requirement as a natural sensitizer. Optical and electrical test are done in order to determine the compliance of the requirement and can be used in DSSC system. To further understand the effect of dye acidity was used to investigate the electron transport characteristics of the fabricated cells. This study shows the correlation between efficiency and stability as a function of the dye acidity.

\section{Experiment}

\section{Chemicals and instrumentation}

Chemicals used for research are krokot, Indium Transparent Oxide (ITO), TiO2 (degusa), KI, I2, polyethylene glycol, ethanol 96\%, Polyvinyl alcohol (PVA), aquades, graphite pencil 8B and detergent. Instrumentation applied for research are Sonikator, ultrasonic cleaner, hotplate, glassware, aluminium foil, paper clips, scothlite, screen proyektor (gasket) and cutter. spektrofotometer UV-Vis single beam, UV-Vis spekular reflektansi UV 1700 Pharmaspec, Fourier Transformation Infra-Red (FT-IR) Shimadzu and I-V meter Keithley 2400 Source Meter.

\section{Preparation of dye-sensitizer}

Ten grams of krokot powder are macerated with $120 \mathrm{~mL}$ of $96 \%$ ethanol for 24 hours. Then, it is filtered by using vacuum filtration and before it is used for further processing, it should be analyzed first using UV-Vis spectrophotometer in the wavelength range 400-700 nm. The effect of $\mathrm{pH}$ of dye solution was studied by adjusting 
$\mathrm{pH}$ from the original $\mathrm{pH}$ of 6.27 using $0.1 \mathrm{M} \mathrm{HCl}$ solution to three different $\mathrm{pHs}(3.0,4.0$ and 5.0).

\section{Preparation of electrodes}

$\mathrm{TiO} 2$ powder was weighed as much as 1.5 grams and then inserted into erlenmeyer and added with $3 \mathrm{~mL}$ of aquades. Then, it is stirred with a magnetite stirring spoon and sonicated with $20 \mathrm{kHz}$ frequency for 2 hours. The next solution was then added with polyvinyl alcohol solution which previously has been made from 0.5 grams PVA added with $6 \mathrm{~mL}$ of aquades by heating at a temperature of $150 \mathrm{oC}$ until all of PVA are dissolved. The mixing is followed by stirring for 10 minutes until it is formed a homogeneous paste.. Then, it is performed $\mathrm{TiO} 2$ paste deposition on surfaces glass of Transparent Indium Oxide (ITO) with Doctor Blanding technique. But before it, ITO should be washed with detergent and followed by aquades using ultrasonic cleaner for 10 minutes and rinsed with ethanol. Before $\mathrm{TiO} 2$ paste is dropped on ITO glass, the conductive part should be found and then each of it is given a scotchlite restraint and it is made a rectangular pattern by leaving a $1.8 \times 1.3 \mathrm{~cm}$ room. Furthermore, in above of that fields, the $\mathrm{TiO} 2$ paste is distributed evenly with a glass rod and then dried in the air and the scotchlite is opened, then it is heated at $80^{\circ} \mathrm{C}$ for 1 hour.

$\mathrm{TiO} 2$ film is inserted into the krokot extract, the container is covered with aluminum foil and then it is saved for an hour. The film which has been soaked then removed and rinsed with ethanol to clean the edge of the layer. Then,it is dried at room temperature and analyzed by UV-Vis reflectance spectrometer and FT-IR. The graphite of a $8 \mathrm{~B}$ pencil is spread into the surface of ITO on the conductive layer with the shading manner to average carbon layer. Then, it is heated at temperature of $300 \mathrm{oC}$ for 1 Hour.

\section{Preparation of electrolytes}

Potassium iodide (KI) is weighed as much as 0.815 grams and then dissolved in $10 \mathrm{~mL}$ of polyethylene glycol (PEG) 400 and stirred until dissolved then added with 0.128 grams of I2 and stirred again until completely mixed. The finished Electrolyte solution then stored in the dark bottles and also sealed.

\section{Assembly of Dye-Sensitized Solar Cells (DSSCs)}

DSSC fabrication which is used is a sandwich construction with a composition such as: glass-ITO working electrode ( $\mathrm{TiO} 2$ layer) that has been coated with dye-screen projector-counter electrode (carbon layer) ITO glass. The use of screen proyector is intended to prevent the short on DSSC system. At the ends of the glass that does not stick together is spilled with the electrolyte solution and allowed to seep between the two layers after it is clamped with paperclip (binder clips) on two opposite sides are not coated.

\section{Measurements}

DSSC prototype was tested by measuring the I-V characteristic curve using a digital multimeter Keithley 2400 , in the light of a xenon lamp at an intensity of 1000 $\mathrm{W} / \mathrm{m} 2$. The result of the $\mathrm{I}-\mathrm{V}$ characteristic curves test were then analyzed Voc, Isc, fill factor, and the efficiency of solar cells [6] by the equation:

$$
\begin{gathered}
F=\frac{V_{m} \cdot I_{m}}{V_{a} \cdot I_{s}} \\
\eta=\frac{V_{a}(V) \cdot I_{s}(A) \cdot F}{F_{i \cdot\left(\frac{W}{c^{2}} \cdot A\left(c^{2}\right)\right.}}
\end{gathered}
$$

\section{Result and Discussion}

\section{The effect of dye pH on the absorption spectra}

The result of characterization of Krokot extract color absorption spectrum in Figure. 3 shows the Krokot extract absorbs the blue spectrum (400-450 nm) and red (650$700 \mathrm{~nm}$ ) with peak absorbance is absorbed at $\lambda=410.5$ with a absorbance value of 0.91 Abs, $\lambda=536.5$ with a absorbance value of $0.567 \mathrm{Abs}, \lambda=608$ with a absorbance value of $0.473 \mathrm{Abs}$ and $\lambda=664.5$ with absorbance values of $0.30 \mathrm{Abs}$ so that from the great absorbance at a wavelength of $410.5 \mathrm{~nm}$ and $664.5 \mathrm{~nm}$ can be known that the more dominant krokot extract contains the pigment chlorophyll.

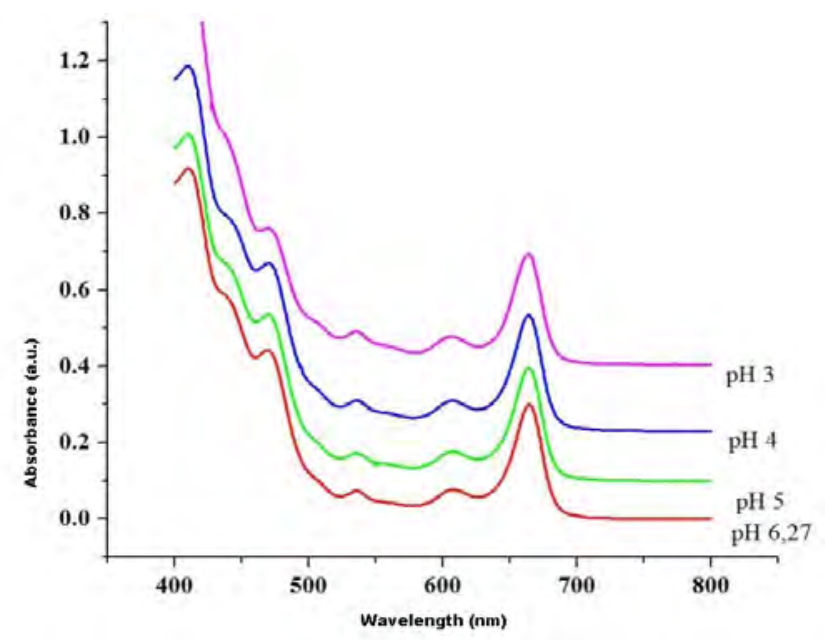

Figure 3. Absorbance of krokot extract.

The effect of $\mathrm{pH}$ was also investigated in absorbance of krokot extract as a dye sensitizer. As shown in Table 1 , the $\mathrm{pH}$ extract solution has not a significant effect on the absorbance. The absorbance was found the chlorophyll pigment in different $\mathrm{pH}$ extract solution of krokot dye. The variation of $\mathrm{pH}$ extract did not effect the absorption peak, two maximum peak were detected in $410.5 \mathrm{~nm}$ and $664.5 \mathrm{~nm}$. 
Table 1. Absorbance of dye sensitizer.

\begin{tabular}{ccc}
\hline $\mathbf{p H}$ & $\boldsymbol{\lambda}$ maximum (nm) & Absorbance (a.u.) \\
\hline \multirow{2}{*}{6.27} & 664.50 & 0.30 \\
& 410.50 & 0.91 \\
5.00 & 664.00 & 0.29 \\
& 410.50 & 0.90 \\
4.00 & 664.00 & 0.30 \\
& 410.50 & 0.95 \\
\multirow{2}{*}{3.00} & 663.50 & 0.29 \\
& 412.00 & 1.02 \\
\hline
\end{tabular}

Figure. 4 showed the absorbance graphic of plot toward different $\mathrm{pH}$ of krokot extract as $\mathrm{TiO} 2$-dye system. The absorbance indicated that $\mathrm{TiO} 2$-dye system of extract krokot dye had a wide electronic absorbance in visible light region. Extract absorbance was shifted into higher wave length or red shift that indicated dye was absorb into $\mathrm{TiO} 2$ surfaces than the $\mathrm{TiO} 2$-dye had lower exited state energy. The red shift showed an electron injection from dyes into semiconductor surfaces.

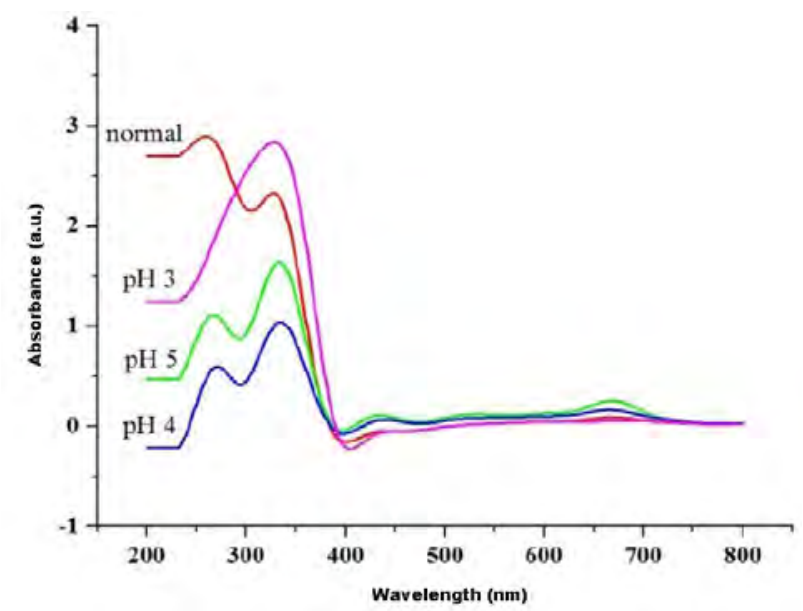

Figure 4. The graph of absorbance to wavelength of thin layer TiO2 dye in different $\mathrm{pH}$ extract dye.

Table 2. Absorbance shift of extract dye.

\begin{tabular}{cccc}
\hline $\mathbf{p H}$ & $\boldsymbol{\lambda}$ dye & $\boldsymbol{\lambda} \mathbf{T i O}$-dye & shift \\
\hline 6.27 & 664.50 & 670.00 & 5.50 \\
5.00 & 664.00 & 669.00 & 5.00 \\
4.00 & 664.00 & 666.00 & 2.00 \\
3.00 & 663.50 & 684.00 & 20.50 \\
\hline
\end{tabular}

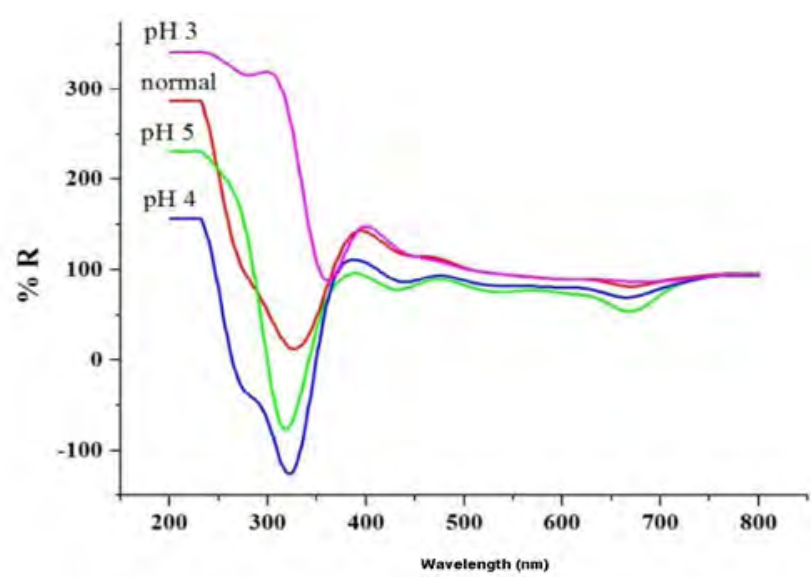

Figure 5. The graph of reflectance to wavelength of thin layer $\mathrm{TiO} 2$ dye in different $\mathrm{pH}$ extract dye
Absorbance is used to calculate the band gap energy (Eg) in the TiO2-dye film by tauc plot method. Figure 6 showed that dyes acidity increased from 3.28, 3.61, 3.42 and $3.38 \mathrm{eV}$ when the $\mathrm{pH}$ of the dyes was adjusted from $6.24,5.00,4.00$ and 3.00. The band gap was influence the semiconductor performance when apllied into dye sensitized solar cells (DSSCs) system. The wide band gap (more than $3.00 \mathrm{eV}$ ) absorb high foton energy from sunlight.

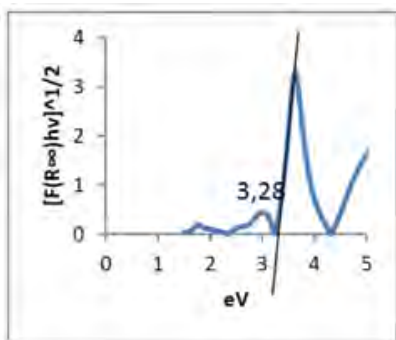

a. $\mathrm{pH} 6,27$

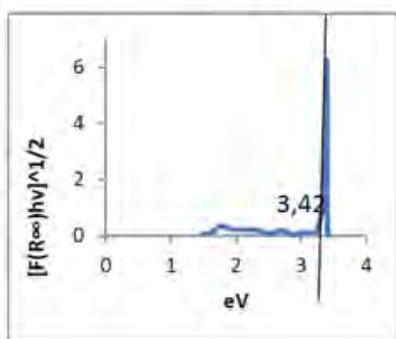

c. $\mathrm{pH} 4$

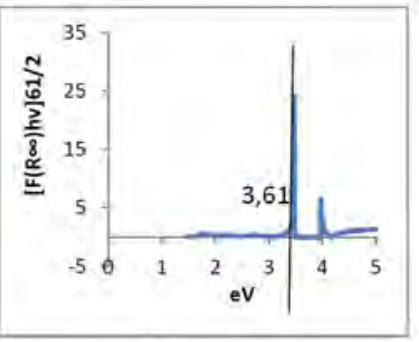

b. $\mathrm{pH} 5$

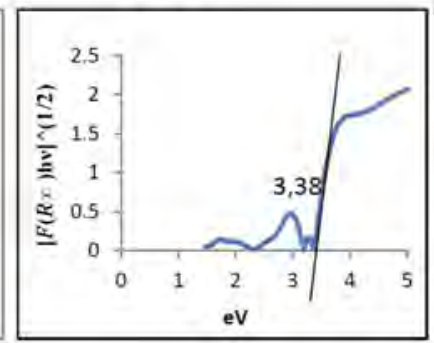

d. $\mathrm{pH} 3$
Figure 6. Energy gap thin layer TiO2-dye.

\section{The effect of dye pH on the FTIR spectrum}

Infrared absorption spectrum of a material has a distinctive pattern so that it possible to identify the material and also shows the existence of the major functional groups in the identified structure. The bond can be estimated if the IR spectra of TiO2-dye system shows the appearance of a significant new peak or functional groups shift if it is compared with the spectra of dye and spectra of $\mathrm{TiO} 2$ film. Krokot extract used in this study contains carboxyl and carbonyl because in the analysis that uses UV-Vis is identified to contain chlorophyll so it is possible there is efficient sensitization through the formation of a bond between the dye and $\mathrm{TiO} 2$. 


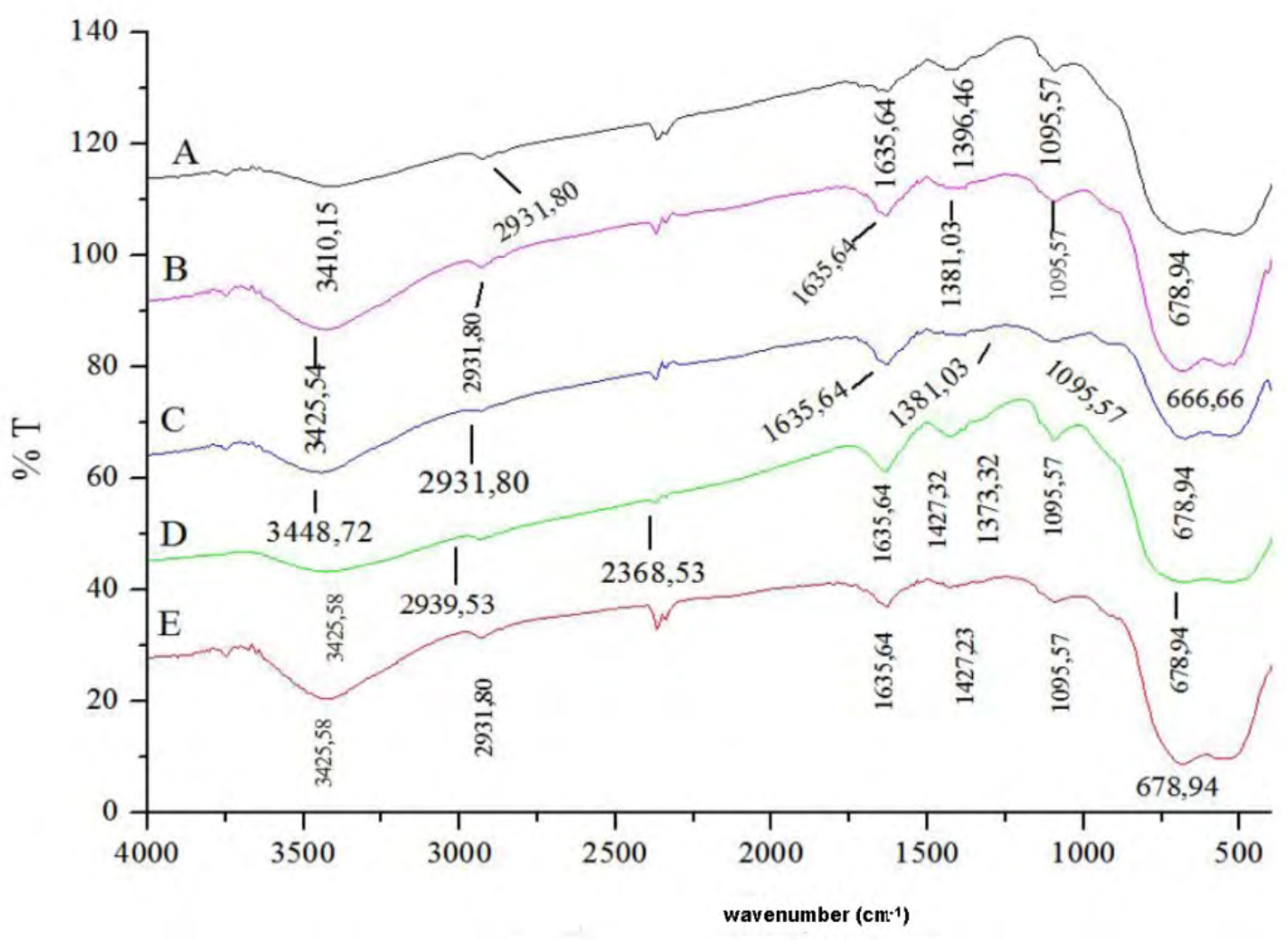

Figure 7. Infrared spectra (A) Thin layer TiO2, (B) Thin layer TiO2-dye $\mathrm{pH} 6.27$ (C) Thin layer TiO2-dye $\mathrm{pH} 5.00$ (D) Thin layer TiO2-dye pH 4.00 and (E) Thin layer TiO2-dye $\mathrm{pH} 3.00$.

The results of FTIR analysis for TiO2 film, and TiO2dye film of Krokot extract is shown in the Figure. 4 which shows the existence of the carbonyl absorption at wave number $1635.64 \mathrm{~cm}-1$ and there is absorption at 3410.15 cm-1 region which is the absorption area of hydroxyl groups. Carbonyl and hydroxyl group that is owned by krokot extract that can bind to the group of $\mathrm{Ti}$ (IV) on TiO2 (Kuzaifah et al 2015).

Table 3. Infrared spectra Thin layer TiO2-dye.

\begin{tabular}{|c|c|c|c|c|c|}
\hline \multicolumn{5}{|c|}{ Wavenumber $\left(\mathrm{cm}^{-1}\right)$} & \multirow{3}{*}{ groups } \\
\hline \multirow{2}{*}{$\mathrm{TiO}_{2}$} & \multicolumn{4}{|c|}{$\mathrm{TiO}_{2}$-dye } & \\
\hline & pH 6.27 & pH 5.00 & pH 4.00 & pH 3.00 & \\
\hline 3425.58 & 3425.58 & 3448.72 & 3425.50 & 3410.00 & $-\mathrm{OH}$ \\
\hline 2931.80 & 2931.80 & 2939.53 & 2931.80 & 2932.00 & $\mathrm{C}-\mathrm{H}$ \\
\hline 1635.64 & 1635.64 & 1635.64 & 1635.60 & 1636.00 & $\mathrm{C}=\mathrm{O}$ \\
\hline 1427.23 & 1427.57 & 1381.03 & 1381.00 & 1396.00 & $\mathrm{C}-\mathrm{C}$ \\
\hline 1095.57 & 1095.57 & 1095.57 & 1095.60 & 1096.00 & $\mathrm{C}-\mathrm{O}$ \\
\hline 678.94 & 678.94 & 678.94 & 666.66 & 678.90 & Ti-O \\
\hline
\end{tabular}

From FTIR analysis is not seen the significant difference from treatment with variation of extract solution acidity. It is only seen the carbonyl absorption shift of in TiO2 film is at a wavelength of $1635.64 \mathrm{~cm}-1$ for natural $\mathrm{pH}$ shifted to a wave number $1636.00 \mathrm{~cm}-1$ for $3.00 \mathrm{pH}$ of extract krokot dye. This shows that Krokot extract does not bind yet optimally with a film of $\mathrm{TiO} 2$ or the interaction possibility that occurs only physical interaction.

\section{The effect of dye pH on the DSSCs efficiency}

A DSSCs efficiency can be characterized with an IVdiagram where the corresponding current $(I)$ at rising voltage $(V)$ is plotted. At a bias of $0 V$ the short circuit current $\left(I_{S C}\right)$ is measured and when the current $0 \mathrm{~V}$ the open circuit voltage $\left(V_{O C}\right)$ is defined. The maximum power output $\left(P_{M A X}\right)$ generated by DSSCs is reached when the product of the current and the voltage is maximal. How efficient a solar cell can convert the power of the incident light into electricity described by electricity conversion efficiency ( $\eta$ ) (Hug et al., 2013). An IV-diagram of DSSCs with different dye solution $\mathrm{pH}$ was showed in figure 8 . 


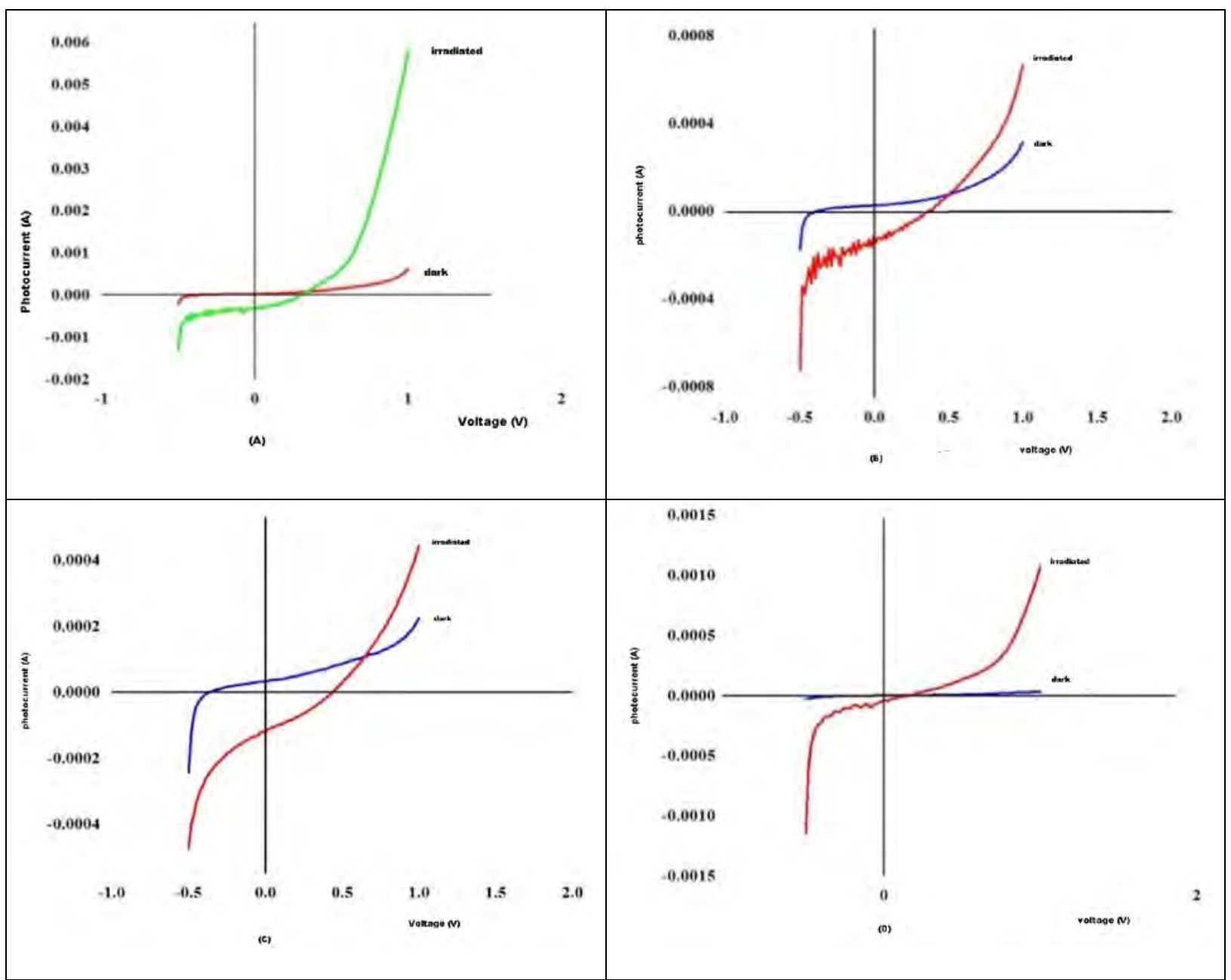

Figure 8. Current-voltage curve for krokot extract dye sensitized solar cell in pH 6.27 (A), 5.00 (B), 4.00 (C) and 3.00 (D).

Table 4 present the performance of DSSCs in the term of short-circuit photocurrent $\left(I_{S C}\right)$, open circuit voltage $\left(V_{O C}\right)$, fill factor $(F F)$ and energy convertion efficency $(\eta)$ (Wongcharee et al 2007). The efficiency was found to decrease with decreased $\mathrm{pH}$ and had maximum at the natural solution $\mathrm{pH}$. The photoanode made from the krokot extract can absorb more light from chlorophyll pigment. As another pigment, chlorophyll was easy to degradation with heat, light, oxidator and $\mathrm{pH}$ (Gross et al., 1991). Pheophytin, a degradation product of chlorophyll, which represents chlorophyll that has lost the central $\mathrm{Mg}$ ion replace with $\mathrm{H}+$ in acidic solution that was colorless breakdown products.

Table 4. Photoelectrochemical parameter of the cells sensitized by krokot extract dye.

\begin{tabular}{ccccc}
\hline $\mathbf{p H}$ & $\begin{array}{c}\mathbf{I}_{\mathbf{s c}} \\
\left(\mathbf{m} \cdot \mathbf{A} \cdot \mathbf{c m}^{-2}\right) \cdot \mathbf{1 0}^{-\mathbf{5}}\end{array}$ & $\begin{array}{c}\mathbf{V}_{\mathbf{o c}} \\
(\mathbf{m V})\end{array}$ & $\mathbf{F F}$ & $\begin{array}{c}\boldsymbol{\eta} \\
(\mathbf{\%}) \cdot \\
\mathbf{1 0}^{-3}\end{array}$ \\
\hline 6.27 & 31.00 & 0.28 & 0.32 & 6.88 \\
5.00 & 12.50 & 0.36 & 0.33 & 3.62 \\
4.00 & 11.50 & 0.44 & 0.33 & 4.08 \\
3.00 & 35.00 & 0.14 & 0.34 & 0.42 \\
\hline
\end{tabular}

In this study, the little DSSC efficiency which is produced can be caused by the performance of the natural dye used is still low due to the effect of the extract used still contains a lot of pigment with the long structure $\mathrm{R}$ which lead steric hindrance of the pigment to the surface band structure so as to prevent oxidation of $\mathrm{TiO} 2$ molecules bind with $\mathrm{TiO} 2$ in effective to cause the transfer of electrons from the conduction band to the dye molecule is reduced (Khuzaifah et al., 2015).

\section{The effect of dye pH on the DSSCs stability}

Dye sensitized solar cells with krokot extract stability was also decrease by adjusting the $\mathrm{pH}$ of the extract from 6.27 to 3.00 . As can be seen from figure 10 efficiency loss of dye sensitized solar cells increased with decreasing $\mathrm{pH}$ from $5.27 \%$ to $97.49 \%$ after irradiated for 2 hours. 


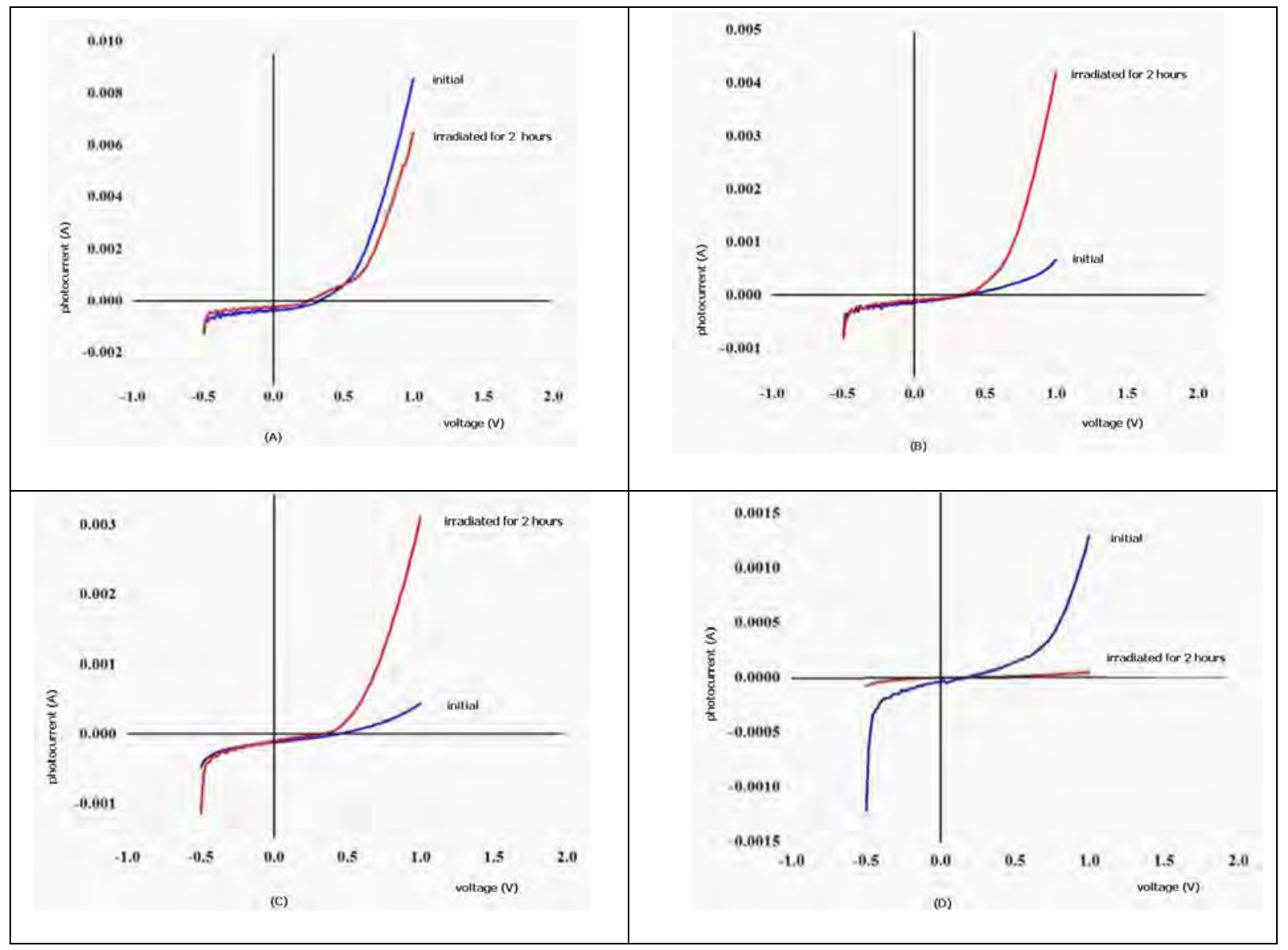

Figure 9. Current-voltage curve for krokot extract dye sensitized solar cell in pH 6.27 (A), 5.00 (B), 4.00 (C) and 3.00 (D) after irradiated.

Table 5. Photoelectrochemical parameter of the cells sensitized by krokot extract dye after irradiated.

\begin{tabular}{ccccc}
\hline $\mathbf{p H}$ & $\begin{array}{c}\mathbf{I}_{\mathbf{s c}} \\
\left(\mathbf{m} \cdot \mathbf{A} \cdot \mathbf{c m}^{-\mathbf{2}}\right) \cdot \mathbf{1 0}^{-\mathbf{5}}\end{array}$ & $\begin{array}{c}\mathbf{V}_{\mathbf{o c}} \\
(\mathbf{m V})\end{array}$ & $\mathbf{F F}$ & $\begin{array}{c}\boldsymbol{\eta} \\
(\mathbf{\%}) \cdot \mathbf{1 0}^{-3}\end{array}$ \\
\hline 6.27 & 28.00 & 0.26 & 0.37 & 6.52 \\
5.00 & 8.90 & 0.31 & 0.45 & 3.02 \\
4.00 & 11.00 & 0.31 & 0.29 & 2.41 \\
3.00 & 0.09 & 0.06 & 0.70 & 0.01 \\
\hline
\end{tabular}

A reason for the worse stability is that, at natural krokot extract acidity the chlorophyll was existed. The pigment are labile and can transformed into the colorless coumpound with decreasing $\mathrm{pH}$. Chlorophyll that has lost the central $\mathrm{Mg}$ ion replace with $\mathrm{H}+$ in acidic solution was degradation into Pheophytin.

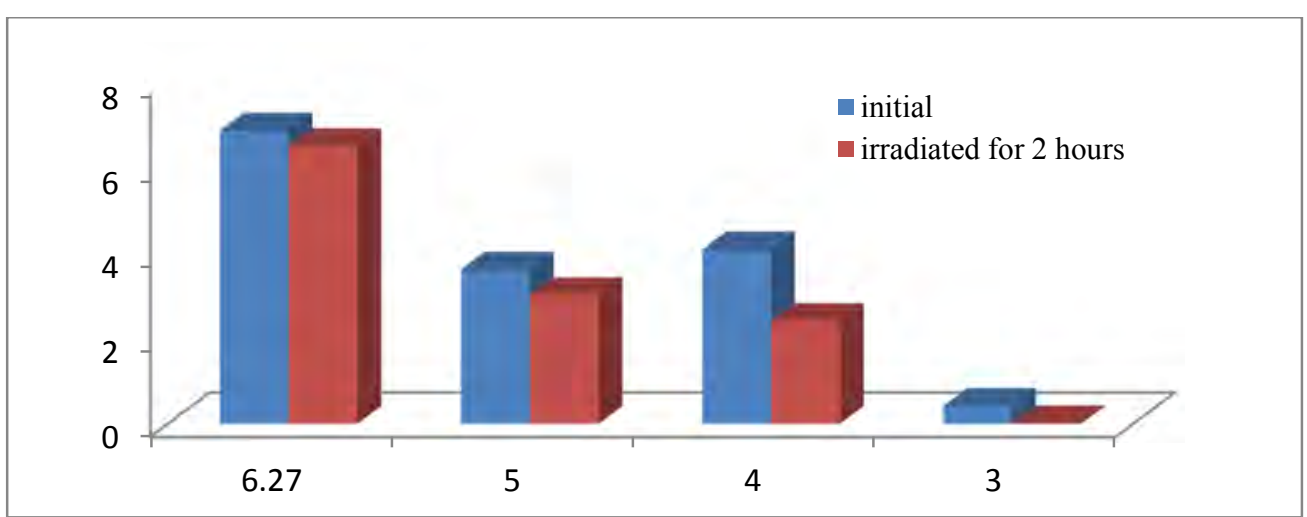

Figure 10. Stability cells sensitized krokot extract. 


\section{Conclusion}

The results shows that the absorbance spectrum of the krokot extract dye is stretched in the range of visible light to the maximum absorbance peak at a wavelength of $410.5 \mathrm{~nm}$ and $664.5 \mathrm{~nm}$ so that can be known that krokot extract dye contains chlorophyll. The efficiency of extract krokot dye sensitized solar cells was decreasing $6.88 \mathrm{x}$ $10-3 \%$ to $0.42 \times 10-3 \%$ when $\mathrm{pH}$ of the dye was adjusted from 6.27 to 3.00. DSSCs stability was also decreased look for efficiency loss from $5.27 \%$ to $97.49 \%$ in the same conditions.

\section{Acknowledgment}

Department of Chemistry, Faculty of Science and Technology UIN Sunan Kalijaga Yogyakarta for academic supported.

\section{References}

Esiyok, D. Ötles, S. and Akcicek E., 2004 "Herbs as a food source in Turkey," Asian Pacific Journal of Cancer Prevention, vol. 5, no. 3, pp. 334-339,

Yan-Xi Zhou, Hai-Liang Xin,Khalid Rahman, Su-Juan Wang, Cheng Peng, and Hong Zhang, 2015.,Portulaca oleracea L.: A Review of Phytochemistry and Pharmacological Effects, BioMed Research International,

U. R. Palaniswamy, R. J. McAvoy, and B. B. Bible, "Stage of harvest and polyunsaturated essential fatty acid concentrations in purslane (Portulaca oleraceae) leaves," Journal of Agricultural and Food Chemistry, vol. 49, no. 7, pp. 3490 3493, 2001

A. I. Mohamed and A. S. Hussein, "Chemical composition of purslane (Portulaca oleracea)," Plant Foods for Human Nutrition, vol. 45, no. 1, pp. 1-9, 1994

Diarra, A. , Hotchandan i, S., Max J - J. and Leblanc R. (1986) Photovoltaic properties of mixed monolayers of chlorophyll a and carotenoids canthaxanthin, J. Cher n . So c. , Faraday Tran 2, $82,2217-2231$.

Griffin, W., Quach, H. and Steepe r, R. (2004) Extraction and thin - layer chromatography of chlorophyll a and $b$ from spinach, Chern . E d. , 81, 385 - 387

Hug, H., Bader, M., Mair, P., and Glatzel, T., 2014 Biophotovoltaics : natural pigments in dye-sensitized solar cells., applied energy., 115., 216-225

Kalyanasundaram, K., and Graetzel, M., 2010, Artificial photosynthesis : biomometric approaches to solar energy conversion and storege., Curr. Opin.Biotechnol, 21: 298-310

Hagfeldt, A.,Boschloo, G., Sun, I., and Kloo, P., 2010., Dyesensitized solar cells., Chem. Rev.,110, $6: 595-663$

O'regan, B and Graetzel, M ., 1991., A low cost high efficiency solar cells based on dye sensitized colloidal $\mathrm{TiO} 2$ films., Nature, 353: 737-740

Ludin, N.A.; Narosikin, A.A.M.; Mahmoud, A.A.; Muhammad, A. A.; Kadhum A.A.H..; Sopian, K.; Nor Karim, S.A. Review on the development of nature dye photosensitizer for dye sensitized solar cell. Renewable And Suinable Energy. 2014, 386-396.

Wang, X.F., Ossamu, K.,Eiji, H., Haoshen, Z.,Shinichi, S., Hitoshi, T., 2010. Tio2 And Zno-Based Solar Cells Using Chlorophyll A Derivative Sensitized For Light-Harvesting And Energi Conversion. Journal Of Photochemistry And Photobiology, $145-152$ 